\title{
"Battle is over, raise we the cry of victory". Study of Revelation 19:11-21
}

\section{"La batalla ha terminado, alcemos el grito de la victoria". Estudio de Apocalipsis 19,11-21}

\author{
Francisco Javier Ruiz-Ortiz \\ Mater Ecclesiae College, St Mary's University \\ Twickenham, UK \\ fjavierruizortiz@gmail.com \\ ID ORCID 0000-0001-6251-0506
}

\begin{abstract}
Using some of the tools of narrative criticism, this article studies the final battle and victory which is achieved by God's envoy. By unpacking the network of relationship in the text the envoy is identified with the Christ of God, who has been present in the book from the beginning. The article shows how the Rider on the white horse summarises what the book of Revelation has said about Jesus.
\end{abstract}

Keywords: Revelation, Christology, Rev 19, final judgment
Resumen: Usando elementos del análisis narrativo, este artículo examina la batalla final y la victoria que se consigue a través del enviado de Dios, un jinete en un caballo blanco. Desenredando la red de relaciones en el texto, el jinete en el caballo blanco se identifica con el Cristo de Dios, que ha estado presente en el libro desde el inicio. El artículo muestra como el Jinete en el caballo blanco resume en sí mismo todo lo que el Apocalipsis dice sobre Jesús.

Palabras claves: Apocalipsis, cristología, Ap 19, juicio final

\section{INTRODUCTION}

In a world dominated by an earth-bound perspective, John ${ }^{1}$ opens for his readers another view of reality, a cosmic dimension is added to the

1 Not much is known about the author of Revelation, other than his name, John (1:1). Unlike other Jewish apocalyptic writings, the Revelation of John is a non pseudoepigraphical work. Cf. Richard BAUCKHAM, The Theology of the Book of Revelation (New Testament Theology), CUP, Cambridge, 1993, 11. For the sake of simplicity, John will be used in this article when referring to the author of the book of Revelation. 
struggles of daily life. The readers of Revelation ${ }^{2}$ down the centuries might have thought that evil conquers but John demonstrates that this is not true. It might seem that Christians are assailed by all-powerful enemies who defeat them no matter what, however, the followers of the Lamb have not lost the battle because, as John proclaims, Christ is victorious.

This article reviews the last Christological image offered by John in the Apocalypse and connects it with all the previous occurrences of descriptions of the Christ. John builds up the image and concept of the victorious Christ all along the book of Revelation but also bases his description on well known Old Testament passages. In this way, this article uses the tools of narrative criticism in order to highlight the complexity of the book of Revelation and of its intertextual connections.

\subsection{General structure of Revelation}

One of the commentators of Revelation writes that there are as many proposed structures for the book of Revelation as there are commentators. ${ }^{3}$ We could say that, in a broad sense, all the approaches to Revelation can be divided into two: those which argue for a linear structure ${ }^{4}$ and those which propose a non-linear one. ${ }^{5}$ Among the non-linear structures, some authors would propose that Revelation has a chiastic structure. ${ }^{6}$ Such a view, however, fails to acknowledge the natural progression of the book.

Despite a break in chapter 4, Revelation should be considered a single unit $^{7}$ which is created by John in different ways. The most relevant one is repetition of the numbers which underpin the plot and the structure of

2 Revelation in this article refers to the book of Revelation. This book will be also called Apocalypse.

3 Cf. Adele Yarbro Collins, The Combat Myth in the Book of Revelation (Harvard Theological Review Series, 9), Missoula, Scholars Press, 1976, 8.

4 Cf. UgoVanni, La struttura letteraria dell'Apocalisse (Aloi 8), Brescia, Morcelliana, ${ }^{2} 1980$.

5 Cf. Frederik David MazzAFERRI, The Genre of the Book of Revelation from a Source-Critical Perspective (BZNW 54), de Gruyter, Berlin, 1986, 331-363, offers a helpful summary of four theories about the structure of the book of Revelation (W.R. Kempson, E.S. Fiorenza, A. Yarbro Collins and J. Lambrecht).

6 Cf. Elisabeth Schüssler Fiorenza, Revelation. Vision of a Just World (Proclamation Commentaries), Minneapolis, Augsburg Fortress, 1991, 34-37.

7 Cf. Giancarlo BiguzzI, Apocalisse. Nuova versione, introduzione e commento (I libri biblici. Nuovo Testamento 20), Paoline, Milano, 2005, 47. Cf. D. Barr who considers the overall narrative of Revelation as three different stories which are artificially united: David L. BARR, “The Story John Told: Reading Revelation for its Plot", in David L. BARR (ed.), Reading the Book of Revelation. A Resource for Students (SBL Resources for Biblical studies 44), SBL, Atlanta, 2003, 11-23. 
the book. ${ }^{8}$ John applies a sevenfold structure to the book of Revelation. There are four septets in the book: ${ }^{9}$ the septet of the letter $(2,1-3,22)$; the septet of the seals $(6,1-8,1)$; the septet of the trumpets $(8,7-11,15)$ and the septet of the bowls $(16,2-17) .{ }^{10}$ The chapters in between these septets prepare for them or develop them. The last chapters of Revelation (1722) recount what will happen at the end of times, by way of presenting the judgment of God's enemies (17-20) and the descent of the New Jerusalem (21-22).

\section{2. $\operatorname{Rev} 19,11-21$ in relation to the rest of the book of Revelation}

Rev 19,11-21 is inserted into the last part of Revelation in which John shows God's intention for humanity, namely, God wants everyone to be saved and arrive at the heavenly city. In order to achieve this goal, God has to do away with the instigators of sin (the Dragon and the two Beasts) and with those who have followed their lead (the kings of the earth). Thus, the episode of 19,11-21 can be related to the battles which are promised in 16,12-16 and 17,12-14.

The last section of the book of the Apocalypse $(17,1-21,8)$ relates a series of visions which present the judgment of the four enemies of God and the descent of the New Jerusalem. These judgments are associated with the preceding chapters in which the enemies of God are presented: Babylon (14,8); the Beast from the sea $(13,1-4)$; the Beast from the land (13,11-18); the Dragon (12,3-18); Hades and Death $(6,8)$. The negative judgments are executed in reverse order of the appearance of these characters. ${ }^{11}$ However, Death and Hades are different from the other characters. They appear so far away from these final chapters, that one should not consider them as part of the reverse order of appearance of God's enemies. Their judgment functions as a way of universalising God's power to decide over all. ${ }^{12}$ In this way, the song of Rev 11,18 is fulfilled: the time has come to judge the dead, to reward God's servants and to destroy those who destroyed the earth. The rewarding of God's servants

8 Cf. James L. Resseguie, The Revelation of John. A Narrative Commentary, Grand Rapids, Baker Academic, 2009, 28-32.

9 Cf. Giancarlo BiguzzI, I settenari nella struttura dell'Apocalisse. Analisi, storia della ricerca, interpretazione (Supplementi alla Rivista Biblica 31), Bologna, EDB, 1996.

10 This septet is based on Wisd 11-19. Cf. Biguzzi, Apocalisse, 304; IDEm, I settenari, 152-153.

11 Cf. BiguzZI, I settenari, 301.

12 Cf. BiguzZI, I settenari, 304. 
takes place during the millennium $(20,4-6)$ and the final judgment of the dead takes place in 20,11-15.

John relates these judgments to each other by means of the characters and of the vocabulary. ${ }^{13}$ Some of characters from one judgement appear in the next. The kings of the earth who gather to fight against the Rider $(19,19)$ are the same kings who had committed fornication with Babylon $(18,3.9)$ and who mourn her ruin $(18,10)$. The Beast and the False Prophet $(19,19-20)$ appear together with Satan $(20,10)$ whereas the dead $(20,4.5)$ feature again in the final judgment $(20,12)$. Furthermore, John's repetition of the vocabulary of judgment ("to judge" in 18,8.20; 19,2.11;

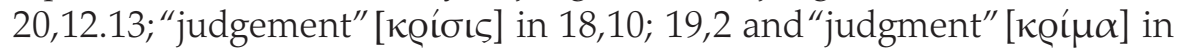
$18,20 ; 20,4)$ creates a unity within this section.

God brings about judgment, either himself (cf. 18,2.8.20; 19,20; $20,10.14)$ or by the hand of an agent $(17,1 ; 18,6 ; 19,11 ; 20,10)$. However, Rev 19,11-21 is the clearest instance of God's intervention in human history through a mediator. He is brought into the scene because the Beast and the False Prophet are so dangerous that they need a direct involvement of Christ. When John describes Satan besieging "the beloved city" $(20,9)$ military language is employed, but God conquers Satan and his armies by merely sending fire from heaven without any other aid. Hence, by setting the image of the Rider in this context, John underscores not only God's action through the mediation of the Rider but also the danger of the Beast and the False Prophet.

They are sentenced by God who does not judge and condemn arbitrarily. Therefore, John gives the reason for their sentence when describing those who are judged. In this part of the book of Revelation, the main reason for receiving a sentence is deceit and idolatry. Moreover not everyone is punished in the same way, whereas the human enemies of God are killed $(19,21 ; 20,9)$, those who instigated the rebellion against God are given a more severe sentence. This verdict against God's enemies should be read as the result of retributive justice. In the same way, as those who are invited to take revenge on Babylon are asked to apply the lex talionis on her $(18,6)$, the most serious crimes are punished more severely. The promoters of deceit and idolatry are sentenced to the definitive punishment of the lake of fire which is "the second Death" $(20,14)$ and they are thrown there alive $(19,20)$. Therefore, the second Death must be interpreted as a continuous punishment suffered as if one was alive. The second Death is not the end of life as experienced on earth, this would be the "first death", but the beginning of what has been called

13 Cf. BiguzZI, I settenari, 311-312. 
in later tradition hell. This view is also supported by the description of the "blessed" as those who were faithful and did not worship the Beast. They reign with God and share in the first resurrection $(20,4)$, which must follow the first death. ${ }^{14}$

Chapter 19 of Revelation begins with a description of the rejoicing in heaven because the wedding feast of the Lamb has come (19,1-10). In so doing, John quotes four times the Hebrew word Halleluiah. This word is a clear reference to Psalms 113-118 which were recited regularly by the Jews as they celebrated Passover. ${ }^{15}$ In this way, John is setting chapter 19 in the context of that feast. The rejoicing in heaven comes because God has delivered his people from Babylon. The end of wickedness has begun, and the fulfilment of Passover is on its way, aided by the arrival of God's messenger.

In this section, not all the judgments are described at the same length. The judgments grow in intensity as John shortens their description. Moreover, the quick succession of events in the judgments reveals that everything happened rapidly. After a battle has been won (19,20-21), John recounts the preparation for another battle which is not even fought (20,9-10). Hence the Rider's victory is highlighted because, once military victory has been won in Rev 19,11-21, no other battle is needed. John leaves many details unspecified because he wants to present the final result of the battle and in this way, show that God is in control of history.

Hence the context in which Rev 19,11-21 is set helps the reader to underline the role of the Rider and of his actions. Another important facet of salvation is that the Christ is not on his own, he is accompanied by the armies of those who are faithful and that subsequently will reign and judge with God (20,4). In the description of Rev 19,11-21, John reassures his audience that God's sphere is the cosmos and his intervention is not outside the realms of history. God sends his messenger to meet his people in their oppression.

Salvation therefore follows the pattern of divine involvement followed by celebration. The contemplation of the grotesque image at 19,21 leaves the reader in need of another image. John, who is a master of imagery, moves the reader to contemplate the joyful period of the millennium $(20,1-6)$. This is the pattern of this section up to the moment when all the enemies of God are destroyed. The overall scene of destruction is replaced by the vision of the New Jerusalem which comes down from heaven (21,1-8).

14 Cf. Biguzzi, Apocalisse, 344-345.

15 Cf. David J. MacLeod, "Heaven's Hallelujah Chorus: An Introduction to the Seven «Last Things» (Rev 19:1-10)", Bibliotheca Sacra 156 (1999) 74. 


\section{STUDY OF REV 19,11-21}

\subsection{Verbal Sequence}

Most of the narration in 19,11-21 is in the aorist, indicating the actions as a whole. The constant nature of the Rider and his armies are described with the present or the imperfect pointing to the on-going nature of the

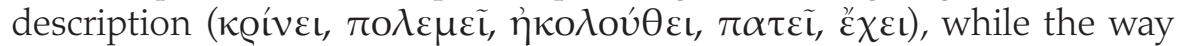
in which the Rider is "King of kings" appears in the future tense and the subjective mood ( $\pi \circ \mu \alpha v \varepsilon \tilde{\mathrm{L}}, \pi \alpha \tau \alpha \dot{\xi} \eta)$ ). In this way, John involves the whole history and expresses that God reaches all time.

\subsection{Structure}

Some commentators tend to treat $\operatorname{Rev} 19,11-21$ as two separate units, ${ }^{16}$ the first one in which the Rider is described $(19,11-16)$ and the second in which the end of the enemies of the Rider is announced and brought about $(19,17-21)$. On the other hand, some scholars treat 19,11-21 as a unity. ${ }^{17}$ I agree with the latter view because there is enough evidence in the text to make 19,11-21 a single unit, which nonetheless consists of three related visions $(19,11-16 ; 17-18 ; 19-21)$ separated one from the

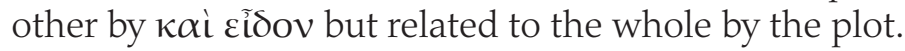

Rev 19,11 begins a new section of the text in which a series of new characters is introduced. This is done by using the expression $\kappa \alpha \mathrm{i}$

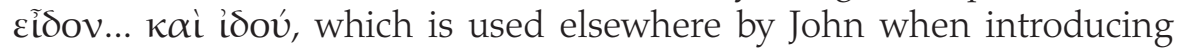
new characters $(6,2.5 .8 ; 12,3 ; 14,14)$ or when he wants to draw attention to a new subject $(4,1 ; 7,9 ; 14,1)$. A new action starts and subsequently concludes. The first pair of actions which are described in 19,11 "he

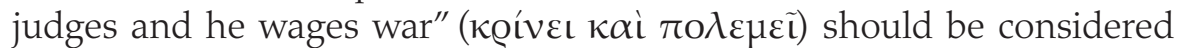
the Rider's main characteristics and the plan of action for what follows. Once those actions have been fulfilled in 19,21 the mission of the Rider is achieved, he disappears from the scene and the unit is brought to a close.

16 Cf. John SweEt, Revelation, (SCM Commentaries), London, SCM Press, 1979, 281. 285; Robert H. Mounce, The Book of Revelation (NICNT 25), Grand Rapids, Eerdmans, 1998, 351; M. Eugene BorING, Revelation (Interpretation 25), Louisville, Westminster John Knox Press, 1989, 194-200. Moreover, in the view of one commentator 20,1-3 is part of this unit, G.R. BEASLEY-MurRaY, The Book of Revelation (NCBC 41), Grand Rapids, Harpercollins - STL, 1978, 277-278. I disagree with this view if one looks at the literary composition of the text.

17 Cf. George K. Beale, The Book of Revelation. A Commentary on the Greek Text (NIGTC 19), Grand Rapids, William B. Eerdmans Publishing, 1999, 949; Pierre PRIgeNT, L'Apocalypse de Saint Jean (Commentaire du Nouveau Testament 140), Genève, Labor et Fides, ${ }^{22} 2000,412$; Biguzzi, Apocalisse, 338; Resseguie, Revelation, 236. 
In two moments, the flow of the account is stopped, one is in verse 14, when the armies of the Rider are described and another one is verses 17-19 when the scene changes. In both cases, John is exercising his narrative technique of creating suspense (cf. 5,4-5; 8,1) in order to draw attention to a main point. ${ }^{18}$ In Rev 19,11-16, John introduces the Rider and then, he draws attention away from him. Afterwards, he focuses the reader on the Rider again. At this point, two aspects of the Rider, the sword with which he conquers and his title of absolute political power, "King of kings and Lord of lords", are highlighted. In this way, John prepares the reader for the importance of the sword which will confirm the Rider as King of kings and Lord of lords.

In a similar way, verses 17-18 cease the flow of the narration and focus the reader's attention on something which seems to be completely dissociated with what has preceded. John creates a tension in the plot by a command addressed to the birds of mid-heaven leaving the reader wonder what the great banquet of God is going to look like. All these questions are answered in the third vision. Thus, John builds the plot of this scene.

\subsection{Commentary of the text}

The unity of the book of Revelation is confirmed by the use of similar images and words in the whole narrative. ${ }^{19}$ This is the reason why the different words and images of Rev 19,11-21 will be related to the whole book of Revelation in order to have a better understanding of this scene. In John's use of Scripture, there is not a word-to-word correspondence between Revelation and the Old Testament. The correspondence is often reduced to a few words. I propose that five texts influenced John in his composition of Rev 19,11-21. Three of them (Is 63,1-3; ${ }^{20}$ Is 11,1-4; Psa 212) are commonly agreed and are quoted by John elsewhere in Revelation,

18 Mathias Rissi defends that, in the case of Rev 19,14, John uses the break in order to distribute the attributes of the Rider in two sections, which finish with two names of the Rider. Cf. Mathias Rissi, The Future of the World. An Exegetical study of Revelation 19.11-22.15 (Studies in Biblical Theology, Second Series 23), London, ScmCanterbury Press, 1972, 19-20. Cf. Charles H. GibLin, The Book of Revelation. The Open Book of Prophecy (Good News Studies 34), Collegeville, Liturgical Press, 1991, 181.

19 Cf.VANNI, Struttura 206-235. Especially, pp. 209-218. 227-233.

20 There is another reference to Is 63 in the book of Revelation (14,19-20). These two passages are related and refer to related actions taken by the Messiah.

21 The reference to Psa 2 is a Messianic one. In this way, John inserts himself in the Jewish and Christian traditions of his time; cf. David E. Aune, Revelation 17-22 (Word Biblical Commentary 52C), Nashville, Thomas Nelson, 1998, 1060. 
whereas two others (Wis 18,14-1622 and Ezk 39,4.17-2023) are alluded here for the first time.

\subsection{1. $\operatorname{Rev} 19,11-16$}

After a series of auditions $(18,4 ; 19,1.6)$, John is introduced to a series of visions $(19,11.17 .19 ; 20,1.4 .11 ; 21,1)$. John sees heaven opened ${ }^{24}$ so that God's salvific judgment can be revealed through the action of the Rider and his armies. ${ }^{25}$ Then John sees a white horse. As on other occasions, John sees first an object and then a person, ${ }^{26}$ pointing in this way to the person by his/her relation to the object. Because white is the colour of radiance pointing out to victory and resurrection in the book of Revelation, ${ }^{27}$ then the Rider is associated with those characteristics.

The reader recalls that a Rider on a white horse $(6,2)$ has been part of the set of four riders $(6,1-8)$. Much has been said and discussed about the relation between the two riders on white horses, ${ }^{28}$ with the conclusion

22 The relationship between these two texts has been highlighted by several commentators, cf. J. Massyngberde FORD, Revelation: Introduction, Translation and Commentary (Anchor Bible), Garden City, Doubleday, 1975, 319; SweEt, Revelation, 283; Aune, Revelation, 17-22, 1049; Mounce, Revelation, 353; Prigent, L'Apocalypse, 420.

23 The prophecy of Ezekiel is one of the Old Testament books which influenced John the most. The influence can be individuated not only upon individual passages but also upon the structure of the book: for example, in the last vision of the New Jerusalem (Rev 21-22 cf. Ezk 40-47). Cf. Albert VanHOYE, "L'utilisation du livre d'Ézéchiel dans l'Apocalypse", Bib 43 (1962) 436-476.

24 This is set in contrast with other images of an opening in heaven which present a communication between heaven and earth (Rev 4,1; 11,19; 15,5 cf. Ezk 1,1; Mk 1,10; Jn 1,51; Act 7,56).

25 Cf. S. Bøe, Gog and Magog. Ezekiel 38-39 as Pre-Text for Revelation 19,17-21 and 20,7-10 (WUNT 135), Tübingen, Mohr Siebeck, 2001, 246.

26 For example, he sees the lamp-stands and then the one like a Son of Man (1,12-13) and in several instances, he sees the place where the character is seated and then he sees the character himself. John sees the throne first $(4,2 \mathrm{a})$ and then he who sits on the throne $(4,2 b-3)$. John sees the different horses connected with the opening of the seals $(6,2 a .4 a \cdot 5 a \cdot 8 a)$ and then those who ride on them $(6,2 b .4 b \cdot 5 b \cdot 8 b)$. Again John sees a white cloud $(14,14 \mathrm{a})$ and then he who sits on it $(14,14 \mathrm{~b})$; cf. Lourdes García UREÑA, Narrative and Drama in the Book of Revelation: A Literary Approach (SNTS.MS 175), Cambridge, CUP, 2019, 72.

27 Cf. Rev 1,14; 2,17; 3,4.5,18; 4,4; 6,2.11; 7,9.13; 14,14; 20,11. Cf. Ugo VannI, "Il Simbolismo nell'Apocalisse", Gregorianum 61 (1980) 487-489; GarCía UreÑA, Narrative and Drama, 40.

28 Cf. Luis M. Guerra SuÁrez, El caballo blanco en el Apocalipsis (Ap 6,1-2 / 19,11-16) y la presencia de Cristo Resucitado en la Historia: Investigación teológico-bíblica, Gran Canaria, Instituto Superior de Teología Islas Canarias, 2004. This thesis offers a comprehensive 
that both riders recall the same positive character ${ }^{29}$ who, despite the differences, is armed, crowned and whose main task is to conquer. ${ }^{30}$

This task is expressed in the description of the Rider in Rev 19 as a just judge and a man of war. Hence the reader expects the subsequent account to elaborate those characteristics. The nature of the Rider is "faithful and truthful", ${ }^{31}$ qualities relating him to the" one like the son of man" who addresses the Church of Laodicea $(3,14)$; to Jesus Christ $(1,5)$ and to God, who is"truthful" $(6,10)$, acts this way $(15,3)$ and judges in this manner $(16,7 ; 19,2)$. John has carefully organised his material to make the reader reach the conclusion that the Rider is an image of Christ while at the same time possessing divine qualities. ${ }^{32}$

John further explores these concepts with the description of the Rider as he who"judges and wages war". The Rider judges, which in the book of Revelation, is God's prerogative ( $\operatorname{Rev} 6,10 ; 16,5 ; 18,8.20$; 19,2; cf. 11,$18 ; 20,12.13)^{33}$ and he administers justice in the manner proper to God in the Old Testament (cf. Lxx Psa 9,9; 10,7; 71,2; 95,13; Isa 11,4). By way of the verb "to wage war" the Rider is described in the same way as "the one like the son of Man" in chapter $2(2,16)$ and the Lamb $(17,14)$. In our text, each verb of the sequence "judges and wages war" explains the other and hence the way in which the Rider judges is the war which is waged and the victory which follows. Judging and making war are two sides of the same coin; the former recalls the judicial decision-making process while the latter points to the punitive action taken on the basis of the decision.

study of the relation between both Riders and concludes that they refer to the same character, Christ, who acts in history with the strength of his resurrection.

29 For references to ancient sources which defend this view, see BiguzzI, Apocalisse, 166, n. 7. Against this view see George B. CAIRD, A Commentary on the Revelation of St. John the Divine (BNTC), London, Black, ${ }^{1} 1984,240$; James Resseguie, Revelation Unsealed. A Narrative Critical Approach to John's Apocalypse, Leiden, Brill, 145, n. 74; Resseguie, Revelation of John, 127; M. Rissi, "The Rider on the White Horse. A study of Revelation 6:1-8", Interpretation 18 (1964) 407-418. Rissi argues that whereas the Rider in Rev 19 is a clear image of Christ, the one in Rev 6 is an image of the Antichrist.

30 The differences can be explained by the metamorphosis that images experience in Revelation. Cf. BIguzzI, I settenari, 128. The actions described in 19,19-21 confirm that the Rider of chapter 19 fulfils the conquering mission that the Rider of chapter 6 came out for. Cf.VAnNi, La struttura, 209-210.

31 Cf. Stephen S. Smalley, Revelation to John: A Commentary to the Greek text, Downers Grove, IL, InterVarsity Press, 2005, 488.

32 Cf. Edmondo LupierI, L'Apocalisse di Giovanni (Scrittori greci e latini), Milano, Mondadori, 1999, 301.

33 The passive voice implies that the subject of the verb is God. Cf. Maximilian Zerwick, Biblical Greek, Rome, PIB, 2005, § 236; ResseGuie, Revelation Unsealed, 47. 
Having presented the Rider through his actions, John complements his reflections on the nature of the Rider by an external description. ${ }^{34}$ John describes first the eyes of the Rider as "fiery flames", which recalls the description of the "one like the son of man" $(1,14 ; 2,18)$ and which refers to the quality the Rider has as judge because he sees clearly. ${ }^{35}$ The fiery eyes connote the purity and powers of perception for judgement that Christ possesses (cf Dan 10,21-12,13, especially 10,6). In our book, Christ sees beneath and has deep knowledge of what's happening in the Church (2,18-26) and in the world (19,11-21).

The description continues with the head attire, namely, the many diadems he wears presenting him as conqueror of many kingdoms and as having eternal power and kingship (cf. 1,5; 17,14; 19,16; cf. 1 Macc 11,13). Thus, the Rider is set in contrast with the Dragon $(12,3)$ and the Beast from the sea $(13,1)$ which, by their possession of diadems, mimic the true kingship of God. ${ }^{36}$ However, the Rider's superiority over his enemies is underlined, by the way in which the Rider is described even before they appear, or they enter into battle. Hence with these two traits of the Rider's description, his eyes and the many diadems, John underlines the role of the Rider as the one who"judges and wages war".

Having described the Rider by his actions and his physical appearance, John now provides the names by which the Rider is known. The first name is public as it is written on the diadems worn by the Rider. The position of the name is set in contrast with the "blasphemous names" of the Beast also written on his diadems $\left(13,1\right.$; cf. 17,3.5). ${ }^{37}$ The name given in verse 12 seems to be no name at all, since"no one knows except him". ${ }^{38}$ However, this name must be put in relation with the other names which appear in the description $(19,13.16)^{39}$ if we want to fully understand it. All the names are related to God and, since they also are

34 Some other examples of this kind of description are the "One like the Son of man" $(1,12-16)$ the Four Living creatures $(4,6-8)$, the Lamb $(5,6)$, the locusts $(9,7-10)$, the strong angel $(10,1)$, the Woman $(12,1-2)$ and the Dragon $(12,3)$, the Beast from the Sea $(13,1-4)$ and that from the Earth $(13,11)$, the Great Prostitute $(17,3-5)$ and the New Jerusalem (21,2). Cf GARCía Ureña, Narrative and Drama, 79.

35 Cf. Resseguie, Revelation Unsealed, 237.

36 Cf. SweEt, Revelation, 282.

37 Cf. Beale, Revelation, 955; Smalley, Revelation, 489.

38 Robert H. Charles, A Critical and Exegetical Commentary on the Revelation of St. John (ICC 14), Edinburgh, Continuum, 1920, vol. 2, 132, defends that this title is a later interpolation resulting from the work of an editor.

39 Cf. Prigent, L'Apocalypse, 418. 
applied to the Rider, they put him and God in close relation revealing the high Christology of this passage..$^{40}$

From the head we are taken to the mantle that covers the Rider. The mantle tells us something of the person under it and is sprinkled with the blood of his enemies. ${ }^{41}$ This interpretation is based on Is 63,1-6, which inspired this text. Some commentators, however, argue that this cannot be the case since there has not been a battle yet. John shows in the Apocalypse that he is not bound by a strict chronological order. The blood of God's enemies on the Rider's clothes states that their fate is due to him, and their suffering is his judgment on them, restating that he is the just judge and the man of war.

Then the Rider is also called "the word of God" highlighting his role as a judge because his very nature is that of judging as God's word. All other occurrences of "the word of God" in the Apocalypse refer to the testimony of the apostles ( $\operatorname{Rev} 1,2.9 ; 6,9 ; 17,17 ; 19,13 ; 20,4)$. Subsequently the word of God is presented in 19,13 as the agent of God's punishment encouraging Christians to be faithful to the word of their testimony. ${ }^{42}$

This title has roots in the book of Wisdom. "The Word of God"appears with a threefold connotation in the book of Wisdom: as part of the merciful healing love of God (Wisd 16,12); as the creative power of God (Wisd 9,1-2); and as the instrument with which deals out punishment (Wisd 18,14-16). Notwithstanding these three aspects, the Word of God is the principal channel whereby God reveals himself to humans. ${ }^{43}$

The Word of God in our text distributes justice, in the same manner as Wisd 18. The main character in both texts is the personified Word of God, which comes out of heaven in order to fulfil a task entrusted to him

40 For other interpretations see: 1) the name of YHWH, cf. Mounce, Revelation, 353; Beale, Revelation, 954; SMALley, Revelation, 490. 2) This name expresses the mystery of Christ's being which finite minds cannot grasp, cf. BEASLEY-MurRAY, Revelation, 279280; Resseguie, Revelation Unsealed, 115.

41 CAIRD, Revelation, 242-243, defends that the blood is that of the martyrs. He bases this choice on his previous exegesis of Rev 14,18-20, in which he thinks that the allusion to Is 63 involves the martyrs as well. Among those who hold that the blood is Christ's: BeAle, Revelation, 959; Prigent, L'Apocalypse, 418; LuPIERI, L'Apocalisse, 303; Aune, Revelation 17-22, 1057; BorIng, Revelation, 196. On the other hand, Mounce defends in his commentary that the blood belongs to the enemies of the Rider, cf. Mounce, Revelation 353; Ben Witherington, Revelation (The New Cambridge Bible commentary), Cambridge, CUP, 2003, 243.

42 This idea of "the Word of God"is different from other instances in the New Testament, in which "the Word of God" refers to God's creative action and the way he reveals his glory $(J n$ 1,14) as well as to the discerning power of God (Heb 4,12).

43 Cf. Michelangelo Priotтo, La prima Pasqua in Sap 18,5-25. Rilettura e attualizzazione (Supplemneti alla Rivista Biblica 15), Bologna, EDB, 1987, 129. 
by God. Wis 18 and Rev 19 share a similar context. ${ }^{44}$ Wisdom, in chapters 11-19, deals with the idolatry that both Egypt and Israel experienced and how God, through the plagues, tried to convert them. For the book of Revelation, the theme of the Exodus is very important. There are direct references to Moses (Rev 15,3), plagues (cf. 8,6-21; 16,1-21) and some other references which are more subtle, such as the references in chapter 12 to the desert $(12,6)$ and to the eagle's wings $(12,14$, cf. Exo 19,4).

Both in Wisdom and the book of Revelation, the image of the sword is integral to the description of what is happening. The sword represents the Word of God which comes to carry out the command of God in the silence of the night whereas the Rider deals out destruction with a sword which is a metaphor for the power of his speech.

After focusing on the Rider, attention is drawn to the "the armies of heaven" $(19,14)$. Like the description of the Rider, his armies are depicted positively by their actions and their outward appearance. They always follow the Rider, in the same way as the 144,000 follow the Lamb wherever he goes $(14,4)$. The emphasis on the purity of the garments worn by the army makes evident that these garments symbolise the holiness of the heavenly army (cf.19,8). The members of this army are the elect who went to battle with the Lamb $(17,14) .{ }^{45}$ The Lamb wages war against the kings of the earth and some faithful elect go out with him to conquer. The armies which follow the Rider $(19,14)$ are conquerors as their white garments symbolise (cf. 3,4.5.18; 4,4; 6,11; 7,9.13). Hence the Rider, as the Lamb, leads the army forth to destroy the enemies of God and in this way he fulfils Psa 2,9 which is alluded to in 19,16. Once they have participated in the Rider's victory, they will be associated with his judgment and his kingship (cf. 20,4). ${ }^{46}$

John resumes the description of the Rider on the white horse, as the one who judges in righteousness and who wages war by pointing to the sword that comes out of the Rider's mouth, just as the one which came out of the mouth of the one "like the Son of Man" $(1,14)$. However, whereas in chapter 1 the sword was not given any specific purpose,

44 Jan FeKKES, Isaiah and Prophetic Traditions in the Book of Revelation. Visionary Antecedents and their Developments (JNSTSup 93), Sheffield, Sheffield Academic Press, 1994, 121 n. 50, says that even though there are close parallels in language and thought between Wis 18,15-16 and Rev 19, the context is not the same.

45 Cf. SweEt, Revelation, 283; Mounce, Revelation, 254; Beale, Revelation, 960; CAird, Revelation, 244; LuPIERI, L'Apocalisse, 303-304; WITHERINGTON, Revelation, 243.

46 Against this view, see Charles, Revelation, II, 134; BeAsley-Murray, Revelation, 281; Aune, Revelation 17-22, 1059; GiBLIN, Revelation, 181. They defend that the armies are angelic as in other New Testament descriptions of the coming of Christ (cf. Mt 13,4042; 16,27; 24,30-31; 25,21-23; Mk 8,38; Lk 9,26; 2 Th 1,7; Jude 14-15). 
here the emphasis is on the punishing tasks of the Rider. ${ }^{47}$ The sword is the instrument used to smite the nations and so the reader expects that this action would be described. Moreover, comparison with the Old Testament background of this text (cf. Is 11,4; 49,2) brings the reader to expect that the sword must be understood metaphorically.

The sword is a messianic military motif. ${ }^{48}$ Isa 49,2 presents the image of the servant of God whose mouth has been made a sharp sword. ${ }^{49}$ So the sword in this context is interpreted in a metaphorical manner. At the same time, this motif assures the original readers of the condemnation of their opponents, while guaranteeing their salvation as faithful followers of God and his Christ.

Further John is inspired by yet another passage from the prophet Isaiah when describing the wine of God's anger (cf Isa 63,1-6) ) $^{50}$ and by the idea earlier in the book of Revelation of judgment as the vintage of the nations $(14,10.17-20)$. God made the idolaters drink the wine of his fury, poured out in the cup of his wrath $(14,10)$. The wine of God's anger is in sharp contrast with the wine of the prostitution of Babylon $(17,2)$ : whereas the former is a representation of God's punishment, the latter is a sign of corruption. Moreover, those who drink one cup will drink the other one as well.

The subject of Isa 63 is God, whereas the subject of Rev 19 is the Rider, who has to be identified with the Christ by the references to Isa

47 FORD, Revelation, 397-398, relates to the Roman idea of the ius gladii. The Roman authority was given a sword as a symbol of the highest authority. With this sword, he could exercise power over life and death.

48 Cf. Richard Bauckham, The Climax of Prophecy. Studies on the Book of Revelation, Edinburgh, T. \& T. Clark, 1993, 210-237; BAUCKHAM, Theology, 67-70; 76-80; 88-92.

49 This text is related to Isa 11,4 , in which the Messiah judges with a scepter $(11,4)$ and not a sword. This change could have been made under some other influences such as LXX which interprets"the rod of his mouth" in Isa 11,4 as"the word of his mouth".

50 In later Jewish exegesis this text refers to the punishment of the foreign nations, cf. Aune, Revelation, 17-22 1061. This text was also used to refer to God's judgment of Rome, cf. See references in Beale, Revelation, 959. Further, there was a tradition in first century Judaism of comparing Isa 63 to Gen 49,11-12 as documented in the Targumim, cf Pierre Grelot, "L'Exégèse Messianique d'Isaie LXIII, 1-6", RB 70 (1963) 371-380. "How beautiful is the King Messiah who is to arise from among those of the house of Judah. He girds his loins and goes forth to battle against those that hate him; and he kills kings with rulers, and makes the mountains red from the blood of their slain and males the valleys white from the fat of their warriors. His garments are rolled in blood; he is like a presser of grapes. How beautiful are the eyes of King Messiah; more than pure wine, lest he see with them the revealing of nakedness or the shedding of innocent blood": Martin McNamara, Targum Neofiti 1: Genesis. Translated, with Apparatus and Notes (The Aramaic Bible 1A), Edinburgh, T. \& T. Clark, 1992, 220. 
$11^{51}$ and Psalm 2,9.52 So John uses this reference to Isa 63 to connect the Rider with God; the Rider behaves as God and reveals himself as the one who "judges and wages war". The change to the future denotes a prophecy as the Rider will accomplish all the messianic tasks ascribed to him. He acts on behalf of God and as his Christ, because he is the ultimate expression of God's wrath, of his judgement and his vindication.

The Rider is then given a third name, "King of kings and Lord of lords" which is a claim to absolute power. The title is also the logical progression of Jesus' own title in 1,5 "the ruler of the kings of the earth". This title is shared by the Lamb. This is a title that in the Old Testament was given only to God as a recognition of his supreme sovereignty over the world. In the book of Revelation, the title signifies that Christ, represented by the Lamb and the Rider, possesses victory and sovereignty over all worldly powers. This title is not self-ascribed but, like in the case of Dan 4, it is given him by those who see his actions.

When comparing the Lamb and the Rider, there are no striking similarities between the physical description of the Lamb $(5,6)$ and that of the Rider $(19,11-16)$. However, they are related by their actions. The Lamb is involved in a war which he will win $(17,14)$ since victory belongs to him as an agent of God (cf. 7,10). The victory of the Lamb is due to his suffering and death $(5,9)$ which he endured for the good of Christians $(5,10)$. The Rider however is not the subject of the verb "to conquer" but he is described as victorious $(19,19-21)$. His victory is the result of his fight against the forces of evil. Associated with both the Lamb and the Rider are groups of followers who will fight at their command. ${ }^{53}$

51 John has already referred to this passage in connection with the Lamb $(5,5)$. Fekkes, in his study of the Old Testament allusions and analogues, argues that John was consistent in his Old Testament allusions. Hence he divides these allusions into different clusters. When discussing the Christological titles and descriptions which appear in Rev 19,11-16, Fekkes argues that the main source is Is 11,4 and Is 63,1-3 (also Is 49,2 is alluded when discussing the image of the sword which comes from the mouth of the Rider). These descriptions, which are interpreted in a messianic way, are taken further by the reference to Psalm 2. Cf. FeKKES, Isaiah and Prophetic Traditions in Revelation, 75.

52 Psalm 2 is the most quoted messianic psalm in the whole of the New Testament (Acts 2,26-27; 4,25-26; 13,33; 19,15; Heb 1,5; 5,5). Revelation alludes to some verses of Psalm 2: Psa 2,1 in Rev 11,18; Ps 2,2 in Rev 6,15; 11,15; 17,18; 19,19; Psa 2,5 in Rev 11,18; Psa 2,8 in Rev 2,26; Psa 2,12 in Rev 11,18. Moreover, what is notable is that Psa 2,9 is only referred to in Revelation within the canonical Scriptures. However, in other Jewish source (Pss. Sol. 17,21-24) Psa 2,9 has a messianic interpretation. Cf. Aune, Revelation, 17-22 1061.

53 Rev 14,4 describes those who follow the Lamb as an army which is ready to enter into battle. Cf. Thomas Stater, Christ and Community. A Socio-Historical Study of 
This name is written on that part of the garment which fell open across the thigh..$^{54}$ In this way, it would contrast the blasphemous names that the harlot has written all over her $(17,3)$. The Rider has been given supreme authority because of his actions of judging with righteousness and waging war." King of kings and Lord of lords" is a title expressing the idea of ultimate ruling over all kings which is taken from Dan 4,37 LXX, ${ }^{55}$ where King Nebuchadnezzar utters this title for God. This title is applied to the Lamb in Rev 17,14 and thus the Rider is to be identified with the Lamb. In that instance, the Lamb is assured victory because he is 'Lord of lords and King of kings' whereas by giving this title to the Rider, John is letting the reader know that the Rider will also conquer once the imminent battle begins.

Both the Lamb and the Rider are the subjects of the verb "to wage war". The Lamb will rule over those who died for the faith and will give them rest $(7,17)$ in the same manner as God does $(21,6)$. John makes the association that the Lamb acts as God's divine agent. The Rider will shepherd the nations with a rod of iron $(19,15)^{56}$ in the same way as the son of the woman in chapter 12,5 . Whereas the action is the same, its object and meaning are different. The Lamb rules as a way of looking after the Christians, whereas the Rider conquers God's enemies.

The Rider is he who "judges and wages war" and John relates him to the other Christological images of the Apocalypse in order to underline this description. Like the "one similar to the Son of Man", the Rider judges while similar to the Lamb, he wages war and conquers. The Rider acts as God's agent fulfilling God's plan for the Church and for the world. Once his mission is accomplished, he disappears from the scene and gives way to the Lamb who will be forever in Jerusalem (21,22-23).

the Christology of Revelation, (JSNTSup 178); Sheffield, Sheffield Academic Press, 1999, 193.

54 Cf. Mounce, Revelation 356. Alternatively, some commentators see the inspiration for the position of this writing in the Roman equestrian statues of conquerors. Cf. Charles, Revelation, II, 137; Ford, Revelation, 323.

55 Cf. Thomas B. SLATER, " «King of Kings and Lord of Lords» Revisited”, NTS 39 (1993) 159-160; Gregory K. BEALE, "The Origin of the Title «King of Kings and Lord of Lords» in Revelation 17.14", NTS 31 (1985) 618-620.

$56 \operatorname{Rev} 19,15$ is a citation from Lxx Psa 2,9. The rod of iron is no longer a symbol of destruction for the ungodly nations, but a sign of protection for Israel. The rod is associated with the royal role of administering justice (Is 11,4; Psa 45,7) and often carries the connotation of punishment (Is 10,5; 30,31; Psa 110,2). In Rev 12,5 the judicial authority of the Messiah is emphasised (cf. Aune, Revelation 6-16, 688). The shepherd employs a rod in order to guide his flock but also in order to defend it from any possible enemies. Hence, the Rider appears as the judge who is strong and unyielding in his mission of judgement. 
None of the names by which the Rider is described are self ascribed, they are given to him and hence they are all referred in the passive $(19,12.13 .16)$. Looking at the names, there is a progressive revelation from the name which no one knows till his full revelation as the cosmic ruler.

Subsequently the description of the Rider takes a two-form pattern: he is described by his outward appearance and by his names. ${ }^{57}$ The description begins in a dynamic manner with the verbs which describe the Rider (judges and wages war) then becomes static and in the final verse turns dynamic. John uses the verbs in order to make this scene move: from the completed actions described by the aorist to the ongoing actions described by the present to the ones yet to come described in the future. All the descriptions focus on the judgment which Christ will execute in the future. In all the descriptions, John identifies the Rider with Jesus Christ, the Lamb and God, so that the Rider is the Christ whose actions are the eschatological assault against God's enemies.

\subsection{2. $\operatorname{Rev} 19,17-19$}

The reader's attention is drawn away from the Rider and his armies to another heavenly image: an angel who stands at the sun and the birds that fly at mid-heaven. The flow of the narrative is discontinued, and the reader is left with the question of what is going to become of the Rider and how the birds in heaven are related to the Rider and his armies. John creates suspense in the narrative, highlighting even more the moment of the final battle. ${ }^{58}$

John inspired his composition at this time on Ezekiel 39, which becomes a pre-text our passage. ${ }^{59}$ From a quantitative point of view Ezekiel describes the invitation to the birds with twice as many words as Revelation. God is the one who prepares the banquet (Ezk 39,17; Rev 19,17:"the great banquet of God"), but he gathers the guests by means of different messengers. In Ezekiel the prophet is commissioned to extend the invitation whereas in Revelation an angel makes the call; only birds are invited in Revelation whereas in Ezekiel, there are also other beasts; while the invitation in Ezekiel is to gather upon the mountains of Israel, there is no local indication in Revelation; whereas in Ezekiel the meal is

\footnotetext{
57 Cf.VAnNi, La struttura, 202, n. 40.

58 Cf. Mounce, Revelation, 357.

59 Cf. Bøe, Gog and Magog, 299.
} 
called a sacrifice, in Revelation is a banquet. Ezekiel speaks of eating and drinking, whereas Revelation speaks only of eating. ${ }^{60}$

Angels are a common occurrence in apocalyptic literature in general and in the book of Revelation in particular. ${ }^{61}$ The task of the angel of Rev 19,17 is to act on behalf of God as his mouthpiece inviting the birds of heaven to come to the great banquet of God. There is a similar image of an angel who makes a proclamation in a loud voice in Rev 18,1-2. In this way, John links the visions of chapters 18 and 19: as the fate of Babylon, which is the first enemy of God, is announced so is the fate of some other enemies of God also proclaimed. Therefore, the reader expects that, as Babylon fell following the proclamation of the angel, so those involved in this proclamation will fall as well.

The reference to the birds that fly in the mid-heaven and the proclamation associated with them, brings the reader of Revelation to recall the proclamation made in 8,13 by the eagle which flies the midheaven. It proclaimed the last three woes and the fulfilment of the seventh trumpet. Furthermore, the reader remembers the image of the angels flying in mid-heaven demanding submission to God, announcing the fall of Babylon and predicting the torment of the followers of the Beast $(14,6-11)$. Hence the images of salvation and punishment are brought to the mind of those who read Apocalypse.

The angel invites the birds which fly in mid-heaven to gather for "the great banquet of God", 62 that is, the banquet prepared by God in which the guests become the menu. ${ }^{63}$ This mention of a banquet recalls the Lamb's supper to which the blessed are invited $(19,9) .{ }^{64}$ Once John explains what sort of banquet the angel is inviting the birds to, the reader realises that this banquet is a parody of the Lamb's banquet. The reader is left to make the connections between both festivities seeing

60 The change from "eating and drinking" to "eating" might have happened in order to avoid associations with the Christian communion, cf Bøะ, Gog and Magog, 283.

61 Cf. Resseguie, Revelation Unsealed, 154-159. Angels in the book of Revelation have different roles: they represent the different Churches $(2,1.8 .12 .18 ; 3,1.5 .7 .14)$; they take part in the heavenly liturgies $(5,2.11)$; they bring about divine judgment $(8,1-$ 9,15); they fight against the enemies of God $(12,7-9)$; they make proclamations $(14,6)$; they show and guide through vision $(17,1 ; 18,1-2 ; 22,6)$ and they interpret some of the visions $(22,8)$.

62 According to Albert Vanhoye, John would have been influenced by Isa 25,6 when making the change of vocabulary to Ezk 39, with the result that Rev 19,17 is a combination of both prophecies. Cf.VANHOYE, "L'utilisation", 474-476.

63 Cf. Boring, Revelation, 200.

64 In this way, John also makes an antithesis of the messianic banquet, which was a feast of joy in the Old Testament (cf. Is 55,1-2; 65,13-14), cf. Aune, Revelation 17-22, 1063. 
that judgment, proclaimed in $\operatorname{Rev} 19,17$, is the other side of the coin of salvation as described in $19,9 .{ }^{65}$ In this way the reader is presented with a choice and asked to take a decision as to what banquet he wants to attend.

The idea of such a peculiar menu as the one described in 19,1718 is common in contemporary apocalyptic literature (4 Ez 6,49-52; 2 Bar 29,4). ${ }^{66}$ John's constant repetition of the word "corpses" might be intended to impress on the reader the goriness of the meal whereas the repetition of $\kappa \alpha$ í emphasises the sum total of the thing listed. ${ }^{67}$ John describes God's judgement of Babylon in a similar way, when the city of Babylon is represented as a harlot, whose flesh is eaten by the beast $(17,16)$. In 19,17-19, John's description of the different types of men whose corpses are eaten comes close to his earlier descriptions of the enemies of God who had pleaded to be hidden from the great day of the wrath of God and of the Lamb $\left(6,15 ;\right.$ cf. 13,16). ${ }^{68}$ In John's view, no one is going to escape the punishing judgment of God. The universality of God's judgment is thus described by $\pi \tilde{\alpha} \varsigma$ and the merisms whereas the certainty of the judgement is proclaimed by the used of the aorist.

\subsection{3. $\operatorname{Rev} 19,19-21$}

John moves the reader's attention from the banquet to another vision in which he introduces a cast of characters, namely, the beast; the kings of the earth and they army, which the reader has met before. The Beast from the sea is described in $\operatorname{Rev} 13,1-4$ as a parody of God and the Messiah: no one is like it $(13,4)$, people worship it $(13,12.14 ; 14,9$; cf. 17,8), it has the signs of death but is still alive $(13,3)$ and it wears ten diadems $(13,1)$. The Beast was then instrumental in bringing about the judgment of

65 Cf. Beale, Revelation, 966.

66 "And Behemoth shall be revealed from his place and Leviathan shall ascend from the sea, those two great monsters which I created on the fifth day of creation, and shall have kept until that time; and then they shall be for food for all that are left" (2 Bar 29,4). "And thou didst give Behemont one of the parts which had been dried up on the third day to dwell in, (that namely) where are a thousand hills; but unto Leviathan thou gavest the seventh part, namely the moist; and thou hast reserved them to be devoured by whom thou wilt and when" (4 Ez 6,52).

67 Repetitions of this kind are not unusual in Revelation as a narrative technique cf. 18,2.

68 The lists in 6,15 and 19,18 are not identical but John repeats traditions in different forms and orders, without changing the main meaning. Cf. FEKKES, Isaiah and Prophetic Traditions in Revelation, 79 n. 39. Moreover, in relating 6,15 and 19,17, there is an example of a linear development of images in the Revelation, cf. VANNI, La struttura, 211. 
Babylon (17,16-17). On the other hand, the kings of the earth are those who are allied with Babylon $(17,2.18 ; 18,3.9)$ and hence they are also under the influence of the Beast. The kings have been summoned for a battle $(16,14)$ by the enemies of $\mathrm{God}^{69}$ a battle which is connected with the scene of Rev 19,19, even though while in chapter 16 the battle is against God the one in chapter 19 is against Christ and his armies $(19,19)$.

A further enemy of God is introduced as the False prophet, who is an associate of the Beast $(16,13)$ and who, elsewhere in Revelation, is called the Beast of the land (only in 13,11) and makes people worship the other Beast (13,12-14). John gives a long description of the False Prophet, using a participial form, which is common in the descriptions of the book of the Apocalypse (cf. 11,7; 12,9.17; 17,1; 18,9.15; 21,9.15). This long digression is not one which recalls the physical appearance of the False Prophet but rather his moral actions. Those who are deceived are described by way of a two-step progression," those who had received the mark of the beast and those who had worshiped its image". In this description, the second part elaborates on the meaning of receiving the mark of the Beast. ${ }^{70}$ John also writes that the False Prophet performs these actions on behalf of the Beast. ${ }^{71}$

Through this description, the basis for the judgment on the Beast and the False Prophet is given, the Beast made divine claims and the False Prophet supported those claims by influencing others to pay heed lest they be persecuted..$^{72}$ The False Prophet is thus put in direct contrast with the Rider, who from the beginning, is the agent of truth and righteousness.

The warlike theme is common to our text and Ezekiel 39 which happens to be a recapitulation of the battle narrated in Ezekiel 38. In the same manner, John applies that structure in order to organise his material. He does so in 19,17-21 and in 20,7-10. ${ }^{73}$ Additionally, John follows a similar structure to that of Ezekiel in as much as he presents the different judgments of the enemies of God before the New Jerusalem coming from heaven can appear (Ezk 36-37; Rev 20,1-6).$^{74}$ Furthermore, John presents the description of the battle in such a way that God shows his glory and at the same time demonstrates his judgments to be true and just (cf. Rev 15,3). The twin theme of judgment and restoration found in

\footnotetext{
69 Cf. Beale, Revelation, 967.

70 As one of the characteristics of the book of Revelation. Cf. Resseguie, Revelation, 23-25.

71 Cf. SMalley, Revelation, 499.

72 Cf. Beale, Revelation, 968.

73 Cf. Beale, Revelation, 979.

74 Cf. Mounce, Revelation, 371.
} 
Ezekiel is also present in Rev 19-21. The reference to the destruction of God's enemies in Rev 19,17-21 is the means whereby Christ will reveal God's name in the deliverance of his people and the judgment of their oppressors. In this way, John shows that the Rider is the instrument that God has chosen to judge and wage war against his enemies.

The end of God's enemies comes rather abruptly and is only described by two verbs in the passive ( $\dot{\varepsilon} \pi \dot{\imath} \sigma \theta \eta \ldots \dot{\varepsilon} \beta \lambda \eta \dot{\theta} \theta \eta \sigma \alpha \nu$ ) pointing out that God is in control of what is happening and that victory is his. ${ }^{75}$ There is no further description of what happened because John is interested only in giving the end result: the vindication and the conquest won by the Rider on behalf of God. It is typical of the Apocalypse that the scenes of conflict are described in the briefest possible way. ${ }^{76}$ Thus, the focus of this battle is on the fate of the Beast, of the False Prophet and of their armies. In the destruction of evil, there is no place for real armed violence, but there is space for imagery of armed violence. ${ }^{77}$

The Beast and the False Prophet are thrown alive into the lake of fire which burns with sulphur. The lake of fire combines the elements of punishment by fire and confinement of a rebellious foe in the imagination of the time, ${ }^{78}$ which is intensified in this text by the addition of the adverbial participle $\zeta \tilde{\omega} v \tau \varepsilon \varsigma$. Once the Beast and the False Prophet are confined to the lake of fire, the rest of the enemies are destroyed. The Rider utters his word, which is the sword that comes out of his mouth to bring about God's justice. The rest are to be identified not only with the kings of the earth, already mentioned $(19,19)$ but also with all those who were deceived by the False Prophet and received the mark of the Beast and worshiped his image..$^{79}$ In this battle, the armies of the Rider have no military function and their role is to witness to God's action in history. ${ }^{80}$

75 With the passive voice, God remains ever present yet a "hidden actor" in the drama. Cf. Boring, Revelation, 154. However, some authors would say that the intended subject of these verbs is the Rider. Cf. Aune, Revelation 17-22, 1065.

76 David Aune, "Apocalypse Renewed: Intertextuality Reading of the Apocalypse of John", in D. L. BARR (ed.), The Reality of Apocalypse. Rhetoric and Politics in the Book of Revelation (SBL Symposium Series 39), Atlanta, SBL, 2006, 64.

77 Cf. BauckHam, Climax, 233.

78 Cf. Adela Yarbro Collins, The Apocalypse (New Testament Message, 22), Wilmington, Michael Glazier, 1979, 137. Cf. Num 16,31-33.

79 Christopher Rowland notes that the description of those who carry the mark of the Beast is different in 19,20 from that of 13,16 where people are given the mark. Here they receive it and thus implies some sort of agreement and acceptance of the message of the False Prophet whereas in 13,16 the False Prophet gives it to them, cf. Christopher Rowland, “The Book of Revelation”, NIB, XII, 700.

80 Cf. Lupieri, L'Apocalisse, 308. Unlike in other Jewish apocalypses, the armies of the Rider have no part in the battle, cf. BAUCKHAM, Climax, 210-212. 


\subsection{Purpose}

In my view there are two main intentions in the writing of this episode, one is to portray God as one who intervenes in history and the other to present what is the end of the enemies of God.

God's intervention is mediated by the Rider on the white horse. John describes the Rider so that the reader of the book of Revelation may identify him with the Christ. Even more, John attributes divine characteristics to the Rider. I will argue that this vision is about the coming of Christ to deliver his people from oppression, to vindicate the saints and to give them a share in his kingship. Christ is presented in terms reminiscent of Old Testament theophanies and the whole of Revelation serves to create an image of him as the one who acts on behalf of God for the salvation of the Church.

Then the community is addressed and exhorted to side with God. Those addressed by this passage were tempted to follow the lead of God's enemies. By presenting the tensions between God and his enemies in the military language of Rev 19,11-21, John wanted to exhort the reader/ hearer to take a decision, either to side with God or with his enemies. Hence John presents the consequences derived from either choice in a narration which is full of images and symbolism.

The reader/hearer has been prepared from the beginning for a judgement by the description of the Rider as the one who "judges and wages war". This judgement occurs in two moments: the passive verbs which refer to God and the verb which are applied to the Rider. In both cases the verbs are in the aorist tense, with the meaning that the action is totally finished. John continues to describe the Rider as Jesus Christ, the Messiah, who possesses divine characteristics and acts on behalf of God as judge and warrior.

The Beast and his allies, on the other hand, were instrumental in fulfilling God's plan by bringing judgment on Babylon $(17,16-17)$, are now destroyed with the advent of the Rider so that God's sovereignty over the earth is reasserted. The victory is however, not by force of arms but by means of the power of God's Word. The reader/hearer is left pondering over the grotesque picture of birds gorging on the flesh of God's enemies. This image shows the absolute sovereignty of God and the end of those who oppose him. In this way, John proclaims the final victory of God over the forces of evil. The reader/hearer is invited to foster an attitude of trust in God and his messenger, heeding the underlining call to align oneself and one's efforts with the forces of good. 


\section{CONCLUSIONS}

\subsection{The Word of God}

In describing the Word of God as carrying human activities, the author of the book of Wisdom prepares for the description in the book of Revelation which would add the messianic features and apocalyptic dimensions to the concept of logos. Revelation modifies the sapiential concept to a Christian perspective. The logos appears in human form as the Rider who, behaving this way, comes as the eschatological Judge. The people John addresses are thus invited to see Jesus as the word of God and the agent who would bring about the fulfilment of God's promise of deliverance from the enemy.

In the context of the Apocalypse, the Word of God goes forth to destroy the enemies of God who have always persecuted the saints; the Word of God gives to the persecutors their taste of God's wrath and slays them with the sword, which comes out of his mouth. This constitutes the last act of the redemption of the faithful, who join in the great banquet prepared by God and witness the feasting on the bodies of their enemies who have been slain. The Word of God acts as the redeemer, bringing about God's judgment on his behalf. In this way, the Christian community is encouraged to persevere and to trust in God who will come to vindicate his people. Chapter 19 is set in the context of the Exodus and while John uses the Exodus imagery, building on the sapiential interpretation, he presents the Messiah as he who"judges and wages war".

\subsection{Function}

The scene described in Rev 19,11-21 portrays the meeting between heaven and earth in a dramatic way in which truth dispels falsehood and casts it into the lake of fire. Christ appears as the conqueror against the forces of evil whose main power is deceit and trickery. His battle for truth is fought with the weapon of his word. John wants to make sure that there is a communication between heaven and earth and that such a channel is open for people to contemplate and participate in.

The judgment of the Beast and the False Prophet is described vividly as a battle. In it, the figure of the Rider as the agent of God's justice is most prominent. This judgment prepares the way for the other battles and judgements at the end of time. John highlights that God's punitive intervention is done through his Christ, without taking away God's importance. He is in the background of the scene, directing the Rider on his task as the one who judges and wages war. 


\subsection{Christology}

Nowhere in Rev19,11-21 is the Rider called Christ or Jesus or the Messiah. However, John depicts the Rider in the same manner he has previously portrayed the Christ, Jesus. John uses external description (nouns and adjectives) and the description of the actions of the Rider (verbs) in order to make his point. The images of the Christ describe to the reader the past, present and future perspective of history. The Lamb is an image of the paschal mystery and the most developed in the Christology of the Apocalypse; ${ }^{81}$ the figure of the "one like the son of man" is an image of the present work of Christ in the Churches; and the Rider on the white horse represents Christ coming to vindicate the saints.

The power of the Rider derives from his connection with the other Christological images of Revelation. The Rider can conquer because he was dead but now he lives forever $(1,18)$, Christ's victory on the cross makes possible all other victories. In this way, Rev 19,11-21 encourages Christians in their struggle against evil by proclaiming that the battle conquered in the past needs to be fought in the present in the expectancy that the future coming of Christ will complete the victory. John encourages his readers with the image of the Exodus. In the same way as God acted then, in the middle of the night, through his powerful word which dealt death and destruction everywhere, he will do it again at the end of time through the action of his word.

Christ is therefore judge and warrior. The various Old Testament allusions and connections with previous descriptions in Revelation enrich the picture of Christ as the sole agent of the divine judgement. John focuses on Christ's confrontation with his opponents. The Rider, who is the Christ and "the Word of God" is presented carefully as the one who has absolute power to open and close $(3,7)$, and as the holy sovereign $(6,10)$.

Rev 19,11-21 is the fulfilment of Christ's promise: "Behold, he is coming with the clouds, and every eye will see him" (1,7). John describes the Rider in such a way that there is no doubt about his identity and his arrival raises the expectations in the reader that the end is nigh. The emphasis of Christ's coming is judicial; Christ arrives to establish God's kingdom on earth by defeating all the enemies of God before the community of the redeemed can established themselves upon the earth. Thus, he fulfils his task as the one who"judges and wages war".

81 Slater does not agree. For him, the most developed image is that of the Rider, cf. Slater, Christ and Community, 61. However, the Lamb gives a fuller imagery (conqueror, judge, light, shepherd...) than the Rider, who appears only as conqueror. 


\subsection{Theology}

The Rider, who is an image of the Christ, is closely linked with God. The Rider comes from heaven, which is the place of God, and then he is described with the same attributes of God. The Word God is mentioned three times $(19,13.15 .18)$ but never as the subject of a verb or an action. However, God is present in the different visions which make up the scene, and He oversees the overall scene. God sends the Rider and the angel to gather the birds that fly in the mid-heaven. God destroys the main instigators of the rebellion against him. Even the grotesque image of the birds gorging on the flesh of "the rest" has a theological implication because the birds of heaven are accomplishing God's judgment on the rebels.

John does not describe the rebellion of a few rulers against God neither does he give an account of how God suppresses dissent. Rather the cosmic battle which described in Rev 19,11-21 is a symbol of worldly humanity as a whole, which gathers against the justice and truth of God. While portraying God's sovereign power over human history, John presents the image of the birds of heaven gorging on the flesh of "the rest" as a rhetorical account which communicates an urgent warning to the readers not to side with the Beast in the ongoing struggles of his days.

John tells his readers that God is active in history and brings about his judgment on all. God, however, acts by means of an emissary, his Christ, who is described in different ways and acquires more and more relevance as the narrative progresses. Christ brings judgment and punishment on all those who refuse to convert, whether they belong to the Church $(2,16)$ or not $(19,21)$. God's judgment on his enemies is described with violent images which disturb modern readership of the book of Revelation such as the vintage picture and the feast at which the birds of heaven gorge of the defeated armies. Behind these images there is an intention to call people to come to God. Moreover, Christ is instrumental in bringing about this judgment because he rules as King of kings and he conquers, he acquires not only many crowns but many diadems and thus God's glory is manifested among the nations.

Therefore, these visions show God's justice as executed by his messenger who comes to judge and wage war against God's enemies, against those who are deceivers and who do not show themselves as they really are. In the daily struggle, Christians are called to persevere and pray:"Come" (Rev 22,17) so that the victory which has been won can be lived out in their lives. 